Tg Dept. of Biochemistry,

Animal Health Research Institute, Mansoura Vet. Lab.

\title{
HEAVY METAL RESIDUES IN BLOOD AND TISSUES OF DUCK IN EL-MANZALA REGIONS IN DAKAHLIA PROVINCE
}

(With 3 Tables)

\author{
By \\ H.A. SHALABY; K.A. DEEB and M. EI-HASHEM
}

(Received at 12/9/2011)

بقايا المعادن الثقيله فى دم وانسجة البط فى منطقة المنزلة بمحافظة الدقهلية

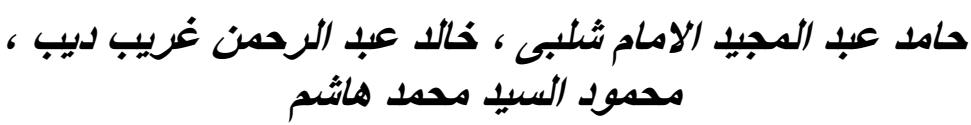

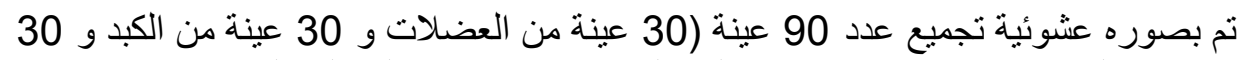

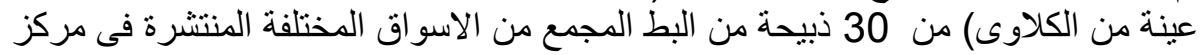

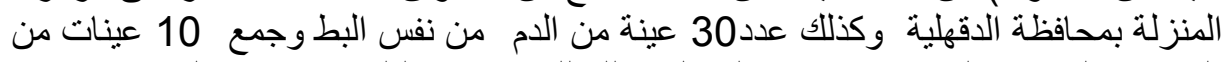

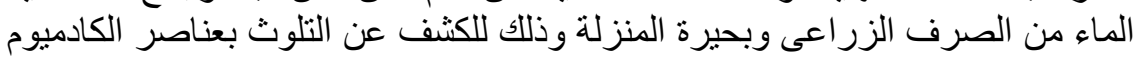

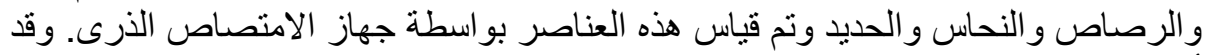

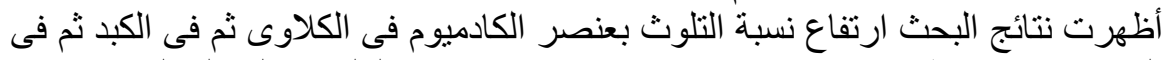

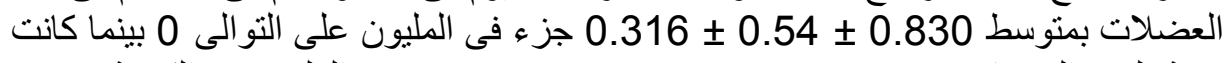

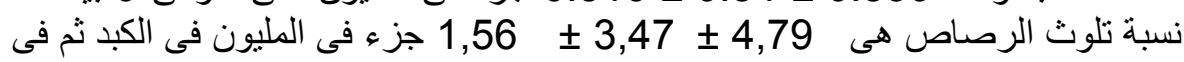

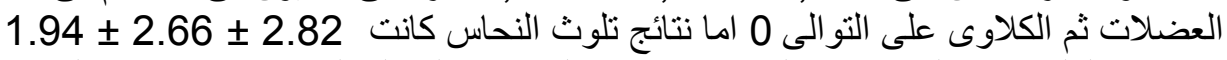

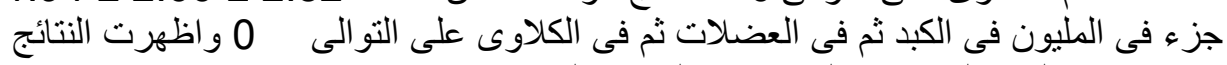

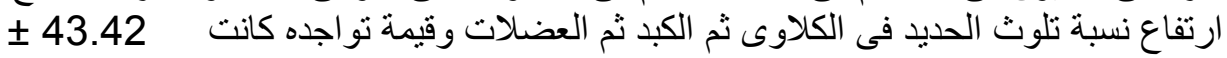

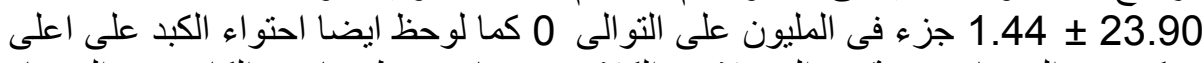

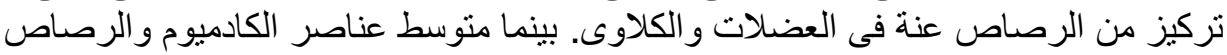

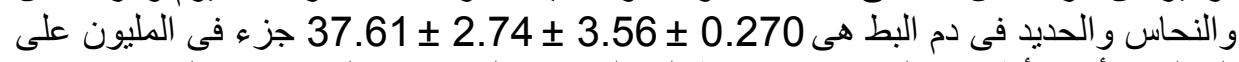

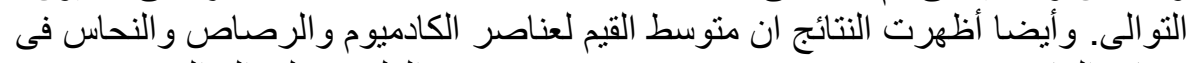

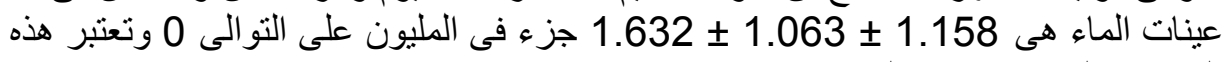
المركبات لهاء اثر ضار على صحة الانسان.

\section{SUMMARY}

The study was conducted on 90 random samples (30 for each of muscles, liver and kidney), which were collected from 30 duck carcasses, from different markets of El-Manzala regions in Dakahlia Province, also 30 blood samples from the same duck and 10 water 
samples (collected from agricultural drainage and Manzala lake). Contamination by cadmium, lead, copper and iron were detected by using Flame Atomic Absorption Spectrophotometer and the results revealed cadmium concentration in kidney, liver and muscle and the values were $0.830,0.54$ and $0.316 \mathrm{ppm}$ respectively. While the lead level contamination were $4.79 \pm 3.47 \pm 1.56 \mathrm{ppm}$ in liver; muscle and kidney respectively. The copper level in liver; muscle and kidney were $2.82 \pm 2.66 \pm 1.94 \mathrm{ppm}$ respectively. Also the iron level in kidney, liver and muscle respectively, were $43.42 \pm 23.90 \pm 10.44 \mathrm{ppm}$. Our results showed that, the highest contamination of cadmium level in kidney then in liver, while the highest level of lead level was in liver then in muscle. Meanwhile the values of cadmium, lead, copper and iron were $0.270 \pm$ $3.56 \pm 2.74 \pm 37.61 \mathrm{ppm}$ in blood serum samples of ducks. Also the results showed that the mean values of cadmium; lead and copper in water samples were $1.158 \pm 1.063 \pm 1.632 \mathrm{ppm}$ respectively. Cadmium and lead level detected in our results in duck tissues and water may have a critical impact on public health.

Key words: Heavy metals, cadmium, lead, copper, iron, ducks.

\section{INTRODUCTION}

Environmental pollution is one of the major problems which create a health hazard to human being and animals. Heavy metals are one of the most important reasons of this pollution. They have a tendency to accumulate in tissue and organs of animals (Mahaffey, 1997; EL- Shorbagy, 2004). Metals are extensively used in the work place and employer and can result from numerous domestic agricultural and industrial effluents, geologic weathering, mining effluents, leaching, rain fall which are being discharged into surface water (Zaki, 1988). Heavy metals in soil and water may enter the food chain through the biologic cycle which includes bio concentration by plant and animals (Goyer, 1992).

The heavy metals cadmium and lead although naturally present in Marine environment, they are nutritionally non essential. Dietary exposure to high levels of these metals can be toxic to avian consumers (Scheuhammer, 1987). Other metals such as copper and iron are essential elements, but may also become toxic if excessively high concentrations are accumulated in tissues (Elliott and Scheuhammar, 1997). 
Heavy metals are directly related to healthy diseases in humans. The presence of cadmium, lead, copper and iron residues in meat and edible offal's duck at significant concentration level are considered as a potential health hazard for consumers (Medani and Ahmed, 1999). Cadmium toxicity affects many target tissues such as appetite and pain centers (in brain), heart and blood vessels, kidney, liver and lungs (Iwegbue, 2008). This toxicity may cause anemia, dry and scaly skin, emphysema, fatigue, hair loss, heart disease, depressed immune system response, hypertension, joint pain, kidney stones or damage, liver dysfunction or damage, loss of sense of smell, lung cancer, pain in the back and legs as well as yellow teeth in humans (Kocak et al., 2005).

Lead is recognized as a toxic substance, which accumulates in the body due to its low rate of slow elimination. Lead can adversely affect many organs, systems and numerous conditions such a hypotension, anemia, kidney damage, mental retardation. When lead level elevated in women it resulted in short gestation period, while young children suffer from mental and physical development retardation (Wagner, 1995; Kocak et al., 2005).

Copper occurs in foods in many chemical forms and has important role in the physiological activities of living bodies. Abnormal high level of copper in the human blood may associate with several diseases as Mediterranean anemia, hemochromatosis, liver cirrhosis and Wilson's disease (Under Wood, 1977). High tissues level of iron correlate with increased risk of myocardial infection (Harvey and Champe, 1994).

Ducks have been recognized as an important source of protein for human consumption. In Egypt, the peoples nowadays prefer to consume ducks meat as it is more palatable and contain more fat content in comparison with those of other poultry of similar age or weight (Brahma et al., 1987).

The objective of this study was to detect concentrations of cadmium, lead, copper and iron residues in livers, kidneys, muscles and serum from ducks as well as the water samples from El-Manzala regions.

\section{MATERIALS and METHODS}

\section{1 - Collection of samples:}

a- The present study was carried out on thirty fresh prepared duck carcasses from different markets of El-Manzala regions in Dakahlia 
Governorate. Ninety specimens of muscle, liver and kidney (30 of each) were collected from investigated ducks in the period between late of May to July 2011. The samples were separately placed in polyethylene bags and kept frozen at $-20^{\circ} \mathrm{C}$ until analysis.

b- Thirty blood samples were collected from investigated duck in plastic centrifuge tubes and left to clot for 3 hours at $4^{\circ} \mathrm{C}$, after that the blood samples were centrifuged to separate the serum and kept in glass vials at $-20^{\circ} \mathrm{C}$ until used.

c- Ten water samples from agricultural drainage and Manzala lake were prepared according to method described by Eaton et al. (1995). Each sample (8ml) was put in screw-capped tube then boiled for 1-3 hours at $130^{\circ} \mathrm{C}$ till complete dryness. $10 \mathrm{ml}$ of $1 \mathrm{~N}$ Nitric acid was put on the sample and boiled till near dryness, then diluted to $20 \mathrm{ml}$ by using deionzied water. The solution was filtrated and diluted to make $100 \mathrm{ml}$ with deionzied water and stored in refrigerator till analysis.

\section{2 - Preparation of samples:}

The samples of muscle, liver and kidney were prepared and digested according to the technique recommended by Al-Ghais, (1995). Two grams from each sample was macerated in screw capped test tube by sharp scalpel. $10 \mathrm{ml}$ of digestion mixture (4 parts of Nitric acid and one part of perchloric acid) were added to the tissue samples. The tubes were tightly closed. The contents were gently shaken and allowed to stand overnight at room temperature for complete digestion. The tubes were warmed at $95{ }^{\circ} \mathrm{C}$ until completely evaporated and then allowed to cool. The residues were re-dissolved in $10 \mathrm{ml}$ of $1 \mathrm{~N}$ nitric acid. The resulting solutions were filtered through ashless Whatman paper No1.

\section{3 - Estimation of heavy metals:}

Assessment of cadmium, lead, copper and iron concentration levels in prepared duck organs, serum and water samples were carried out using Flame Atomic Absorption Spectrophotometer (Perkin Elmer, model 3100 made in USA) according to Scheuhammer and Bond, (1991). The estimation of heavy metals residues of each sample was in ppm.

\section{4 - Statistical analysis:}

Statistical analysis was carried according to Petrie and Watson (1999). 
Assiut Vet. Med. J. Vol. 57 No. 131 October 2011

\section{RESULTS}


Table 2: Mean ( \pm S.E. $)$ concentrations of heavy metals $(\mathrm{ppm})$ in serum samples of examined ducks. $(n=30)$

\begin{tabular}{|l|c|c|c|}
\hline Heavy metals & Min. & Max. & Mean \pm S.E. \\
\hline Cadmium & 0.010 & 0.690 & $0.270 \pm 0.035$ \\
\hline Lead & 0.181 & 4.01 & $3.56 \pm 0.538$ \\
\hline Copper & 0.417 & 5.22 & $2.744 \pm 0.263$ \\
\hline Iron & 8.22 & 75.24 & $37.614 \pm 2.70$ \\
\hline
\end{tabular}

Table 3: Analytical results for heavy metals residues ( $\mathrm{ppm})$ in water samples collected from AL-manzala regions: $(n=10)$

\begin{tabular}{|l|c|c|c|c|}
\hline \multicolumn{1}{|c|}{ Heavy metals } & Min. & Max. & Mean \pm SE & P.L \\
\hline Cadmium & 0.208 & 2.125 & $1.158 \pm 0.208$ & 0.7 \\
\hline Lead & 0.427 & 2.54 & $1.063 \pm 0.188$ & 0.5 \\
\hline Copper & 0.681 & 3.55 & $1.632 \pm 0.278$ & 2.0 \\
\hline
\end{tabular}

- 10 samples examined.

P.L. is the permissible limits by ppm.

Permissible limits according to WHO, (1993).

\section{DISCUSSION}

The analytical results listed in Table (1) showed that the mean cadmium concentration levels in muscle, kidney and liver of duck carcasses were $0.316 \pm 0.043,0.83 \pm 0.137$ and $0.54 \pm 0.065 \mathrm{ppm}$ respectively, exceeded the permissible limits of cadmium in poultry tissues $(0.05 \mathrm{ppm})$, recommended by FAO / WHO, (1992). The obtained results are coincide with Medani and Ahmed, (1999); Abdel-Dayem, (2004) and Sanya El-Ghamry et al. (2008). The levels of cadmium in examined ducks were highest in kidney followed by liver and muscles. These findings agreed with those reported by Lee et al. (1989); Abd ElKader and El-Atabanay, (1994), which stated that the kidney as being the major storage site for cadmium. Cadmium bound to albumin and other high molecular weight proteins, and then the liver takes up cadmium from plasma, where it induces synthesis of metallothionein. Mainly, the cadmium-metallothionien in plasma is effectively filtered 
through the renal glomeruli then reabsorbed in the proximal tubule where it gradually accumulates (Koriem et al., 2009). Thus the elimination of cadmium from the kidney is very slow, with a biological half-life of several decades (FAO/ WHO, 1992).

Table (1), declared that the mean values of lead in muscle, kidney and liver of ducks were $3.47 \pm 0.57,1.56 \pm 0.22$ and $4.79 \pm 0.51$ ppm respectively. These exceeded the permissible limits of lead in poultry tissues (0.5 ppm), recommended by FAO / WHO, (1992). These findings were much higher than that previously determined by Medani and Ahmed, (1999); Abdel-Dayem, (2004); Sanya El-Gamry et al. (2008). It was found that the liver have the highest value of lead followed by muscles and kidney. The obtained results agree with, (Abdel-Kader and Atabany 1994) and Ahmad, (2002), who found that the high concentration of lead in liver, muscle and kidney of examined ducks may be attributed to the dietary habit of ducks. Regarding to public health significance, lead is a cumulative poison that causes both acute and chronic intoxication, acute poisoning is rare but chronic poisoning is more common and serious (Gossel and Bricker, 1990). Also severe and chronic exposure of lead causes hematological, gastrointestinal and neurological dysfunction and may also lead to chronic nephropathy, hypertension and reproductive impairment, (Friend, 1987).

Concerning copper in different tissues of ducks, Table (1) showed that the mean concentration in muscle, kidney and liver were $2.66 \pm 0.26 ; 1.94 \pm 0.29$ and $2.82 \pm 0.32 \mathrm{ppm}$ respectively. In this respect, Nassar et al. (1998), determined 3.6 and 3.8 ppm copper residues in muscle and liver of broiler. The obtained results were lower than the permissible limits of copper in poultry tissues (15, $20 \mathrm{ppm})$ recommended by Pearson, (1976) and FAO / WHO, (1992). Moreover, similar results were reported by Sanya El-Ghamry et al. (2008) in liver $(2.23 \mathrm{ppm})$, while in muscle recorded $(0.83 \mathrm{ppm})$. Copper is known to be essential at low concentrations but it's toxic effect at high levels. Accordingly ingestion of an excessive dose of copper may lead to sever nausea, hypertension, jaundice and bloody diarrhea. Moreover, chronic copper poising may result in what known Wilson's disease which manifested by destruction of nerve cells, liver cirrhosis, edema, ascitis and hepatic failure (Gossal and Bricker, 1990).

The mean values of iron in muscles, kidney and liver of ducks were $10.44 \pm 1.18 ; 43.42 \pm 2.77$ and $23.90 \pm 2.09$ ppm respectively. It was 
noticed that the kidney exhibits the highest level of iron followed by liver and muscles. These results are agreed with VanWyk et al. (2001), who found that the highest level of iron in kidney then in liver and muscle.

Concerning heavy metals residues in serum samples Table (2) showed that the mean values of cadmium, lead, copper and iron were $0.270,3.56,2.74$ and 37.61 respectively. The obtained results coincided with those reported by VanWyk et al. (2001), who found that the high levels of heavy metals in blood resulted from pollution of soil, water and air through mining, refining and smelting operations. Other sources of environmental contamination of heavy metals include the combustion of fossil, fuel, municipal waste incineration and agricultural practices including the use of phosphate fertilizers and sludge amendment for soil, (Friberg et al., 1986; Goyer, 1986).

Regarding to heavy metal levels in water samples collected from different regions of El-Manzala, Table (3) showed that the mean values of cadmium, lead and copper residues were 1.158, 1.063 and $1.632 \mathrm{ppm}$ respectively. These concentrations were exceeded the permissible limit recommended by WHO, (1993). It is obviously clear that the water of El-Manzala were heavily polluted with such heavy metals. The obtained results nearly agree with those recorded by Aeria, (1998); Medani and Ahmed, (1999) and Ahmad, (2002). The obtained results could be interpreted as El-Manzala water mainly receives from Bahr ElBaqar, which carries the untreated sewage of four Governorates, Cairo, Qallyobia, Sharkia and Dakhalia (Khalil and Salib, 1986). Heavy metal pollution in water is generally associated with industrial, agricultural and municipal discharges (Zaghloul, 2000; El-Dessouky et al., 2007). The highly concentrations of heavy metals (cadmium, lead and copper) among the water samples collected from different locations in ElManzala could be attributed to the differences in the effluents (waste municipal, agricultural drainage water also from the decomposition of the organic matter and the use of fertilizers and other chemicals in agriculture. This is in agreement with Nagdi and Shaker, (1998); Zaghloul, (2000); El-Dessouky et al. (2007). When ducks repeat consumption of water polluted by such heavy metals, irreversible progressive will occur in their body as accumulative effect reaching as high as in water, a process called biological magnification. It reflects the toxic effect of these metals on duck or human consumes their meat 
in form of serious diseases on the long run. Metal levels in blood provide information about recent exposure (Mautino and Bell, 1986; Evers et al., 1998). Further more, blood levels of certain metals are influenced by total body burden or levels in organs such as liver and kidney. This is because of a continual process of equilibration between levels of metals in blood and various soft tissues in which metals may be stored over the long-term, (WayLand et al., 2001; Olsson et al., 2005).

From the above mentioned results, it can be concluded that the presence of heavy metals contaminants in duck meat and organs may act as an additional source of hazard for human causing considerable economic loss.

Preventive measures intended for minimizing the heavy metals residues in duck tissues are of significant concern.

\section{REFERENCES}

Abd El-Dayem, R.H. (2004): Detection of lead and cadmium in muscle, gizzards and livers of broilers chickens. J. Egypt, Vet. Med. Assoc. 64, (1): 127.

Abd El-Kader, M.A. and El.-Atabany, A. (1994): Heavy metals residues in chicken tissues and its public health importance. Zag. Vet. J. 22, 2: 188-194.

Aeria, F.M. (1998): Some pathological studies on naturally and experimentally intoxicated fishes with heavy metals. Ph.D. Thesis, Fac. of Vet. Med., Suez Canal University, Egypt.

Ahmad, W.M.S. (2002): Studies on heavy metals pollution in poultry farms in relation to production performance. $\mathrm{Ph}$. D. Thesis, Fac. of Vet. Med., Zagazig University, Egypt.

Al-Ghais, S.M. (1995): Heavy metal concentrations in tissues of Sarus, Sabra forkal.Bull. Enviro. Contam. Toxicol., 55: 581.

Brahma, M.L.; Nath, D.R. and Narayanarao, P.L. (1987): The proximate composition, muscle fiber diameter and shear force value of duck and hen meat. Cheiron, 14 (4) 200.

Eaton, A.D.; Clasceri, L.S. and Greenburg, A. (1995): Standard methods for the examination of water and waste water. $19^{\text {th }}$ ed. A.P.H.A., Washington D.C. 
El-Dessouky, S.A.; Rawia S.M. Adawy and Shalaby, H.A. (2007): The influence of some heavy metals on Clarias Gariepinus in polluted water with special stress on some physiological and pathological changes on these fishes. Assiut Vet. Med. J. 53 (115): 118-148.

Elliott, J.E. and Scheuhammer, A.M. (1997): Heavy metal and metallothionein concentrations in seabirds from the Pacific Coast of Canada. Marine Pollution Bulletin, 34, 10: 794-801.

El-Shorbagy, I.M. (2004): Lead and cadmium residues in meat retailed at Sharkia markets. SCVMJ, VII (1): 71-82.

Evers, D.C.; Kaplan, J.D.; Meyer, M.W.; Reaman, P.S.; Braselton, W.E.; Major, A.; Burgess, N. and Scheuhammer, A.M. (1998): Geographic trend in mercury measured in common loon feathers and blood. Environmental Toxicology and Chemistry 17: 173-183.

FAO/ WHO, (1992): Codex Alimentaious Commission, Standar Programme Codex Committee on food Additives and contamination $24^{\text {th }}$ Session Hagve, Rome.

Friberg, L.; Elinder, C.G.; Kjellstrom, T. and Nordberg, G.F. (1986): Cadmium and health: A toxicological and epidemiological appraisal. Vol. II. Effects and responses. Boca Raton, FL.:CRC Press ; pp. 257-287.

Friend, M. (1987): Lead poisoning in field guide to Wildlife diseases Friend, M. (ed), Fish and Wildlife Service, Washington, D.C., pp. 175-189.

Gossel A.T. and Bricker, J.D. (1990): Metals in principles of clinical toxicology $2^{\text {nd }}$ Ed., pp.162-192, Raven Press, New York.

Goyer, R.A. (1986): Toxic effects of metal. Doull J. Klaassen CD, Amdur MD (Eds.). Casaret and Doull's toxicology: the basic science of poisons. New York: pp. 582-635.

Goyer, R.A. (1992): Toxic effects of metal in : Mary, O.A. ; John, D. and Copperrits, D.K. (Eds.): Toxicology $5^{\text {th }}$ ed., Pergamon press, New York. Pp. 623.

Harvey, R.A. and Champe, P.C. (1994): Lippincott's IIIustrated reviews; East Washington square, Pennsylvania. $2^{\text {nd }}$ Ed. Pp. 309-312.

Iwegbue, C.M.A. (2008): Heavy metal composition of livers and kidneys of cattle from Southern Nigeria. Vet. Archiv., 78, 401-410.

Khalil, M.T. and Salib, E.A. (1986): Effects of some water quality parameters on fish composition and productivity. Egypt Proc. Zool. Soc. ARE, 12: 101-109. 
Kocak, S.; Tokusoglu, O. and Ayean, S. (2005): Some heavy metals and trace essential detection in canned vegetable foodstuff by differential pulse polarography. Elect. J. Enviro. Agric. Fd. Chem., 4: 871-878.

Koriem, K.M.M.; Farrag, A.H.; Badawy, M.A. and El-Toumy, S.A. (2009): Role of some Egyptian medicinal plants against liver and kidney toxicity induced by cadmium chloride. Toxicology Mechanisms and Methods, 19(8): 524-534.

Lee, D.P.; Honda, K.; Tatsukawa, R. and Won, P. (1989): Distribution and residue level of mercury, cadmium and lead in Korean birds. Bull. Environ. Contam. Toxicol. 43: pp. 550-555.

Mahaffey, R.K. (1997): Mineral concentrations in animal tissues: certain aspects FDAS regulatory role. J. Animal Sci., 44 (3): 409.

Mautino, M. and Bell, J.U. (1986): Experimental lead toxicity in the Ring-Necked Duck. Environmental Research 41: 538-545.

Medani, G.G. and Ahmed, A.M. (1999): Cadmium; copper and lead residues in meat and edible offals of migratory quail at El-Manzala lake. SCVMJ. II (2), 373-384.

Nagdi, A.Z. and Shaker, I. (1998): Effect of water sources on some microelements in fish farm. Egypt, J. Agric. Res., 76 (1): 351-357.

Nassar, A.M.; Shoeib, H. and Imam, W.F. (1998): Evaluation of microelements in muscles and some organs of broilers fed with excessive dietary mineral mixture. Assiut Vet. Med. J.40 (79): 179-189.

Olsson, I.M.; Eriksson, J.; Oborn, I.; Skerfving, S. and Oskarsson, A. (2005): Cadmium in food production systems: a health risk for sensitive population groups. Ambio 34: 344-351.

Pearson, D. (1976): The chemical analysis of feed. Churchill Livingstone, London.

Petrie, A. and Watson, P. (1999): Statistical for veterinary and animal science. $1^{\text {st }}$ Ed. The Black Well Science itd., United Kingdom.

Sanya El-Ghamry; Morshdy, A.M.; Hafez, A.E. and El-Gaml, A.M. (2008): Heavy metal residues in marketed duck carcasses. Zag. Vet. J. 36, 1: 122-127.

Scheuhammer, A.M. (1987): The chronic toxicity of aluminium, cadmium, mercury and lead in birds: A review. Environmental Pollution. 46: 263-295.

Scheuhammer, A.M. and Bond, D. (1991): Factor affecting the determination of total mercury in biological samples by 
continuous flow cold vapor atomic absorption spectrophotometry. Biological Trace Elements Research 31: 119-129.

Underwood, E.J. (1977): Trace elements in human and animal nutrition $4^{\text {th }}$ ed., Academic Press. Harcaurt Brace Jovanovich Publishers, New York.

VanWyk, E.; Van der Bank, F.H.; Verdoorn, G.H. and Hofmann, D. (2001): Selected mineral and heavy metal concentrations in blood and tissues of vultures in different regions of South Africa. South African J. of Anim. Sci., 31 (2): 57-62.

Wagner, H.P. (1995): Determination of lead in beer using zeeman background corrected graphite furnace atomic absorption spectrometry J. Am. Soc. Brew. Chem., 53: 141-144.

Wayland, M.; Garcia Fernandez, A.J.; Neugebauer, E. and Gilchrist, H.G. (2001): Concentrations of cadmium, mercury and selenium in blood, liver and kidney of common eider ducks from the Canadian arctic. Environmental Monitorring and Assessment 71: 255-267.

WHO, (1993): Guide lines for drinking water quality $2^{\text {nd }}$ ed. Vol. (1). Recommendation, WHO, Geneva.

Zaghloul, K.H. (2000): Effect of different water sources on some biological biochemical aspects of the Nile tilapia, Oreochromis niloticus and the Nile catfish, Clarias gariepinus. Egypt, J. Zool., (34): 353-377.

Zaki, M.S.A. (1988): Heavy metals in fresh and salted marine fish. $4^{\text {th }}$ Vet. Med. Zag. Congress (26-28 Aug., 1988): 331-340. 
Assiut Vet. Med. J. Vol. 57 No. 131 October 2011 
Table 1: The concentrations of heavy metals residues (ppm) in muscle, kidney and liver of duck $(\mathrm{n}=30$ for each)

\begin{tabular}{|c|c|c|c|c|c|c|c|c|c|c|c|c|}
\hline $\begin{array}{l}\text { Heavy } \\
\text { metals }\end{array}$ & \multicolumn{3}{|c|}{ cadmium } & \multicolumn{3}{|c|}{ Lead } & \multicolumn{3}{|c|}{ Copper } & \multicolumn{3}{|c|}{ Iron } \\
\hline Organs & Min. & Max & Mean \pm S.E & Min & Max. & Mean \pm S.E & Min & Max. & Mean \pm S.E & Min. & Max. & Mean \pm S.E \\
\hline Muscle & 0.01 & 0.92 & $0.32 \pm 0.04$ & 0.38 & 4.22 & $3.47 \pm 0.57$ & 0.34 & 5.15 & $2.66 \pm 0.26$ & 2.95 & 29.36 & $10.44 \pm 1.18$ \\
\hline Kidney & 0.19 & 3.10 & $0.83 \pm 0.14$ & 0.07 & 3.56 & $1.56 \pm 0.22$ & 0.20 & 5.48 & $1.94 \pm 0.29$ & 23.58 & 77.98 & $43.42 \pm 2.77$ \\
\hline Liver & 0.05 & 1.08 & $0.54 \pm 0.07$ & 0.56 & 5.14 & $4.79 \pm 0.51$ & 0.22 & 6.35 & $2.82 \pm 0.32$ & 7.81 & 44.27 & $23.90 \pm 2.09$ \\
\hline P.L. & & & $0.05^{\mathrm{a}}$ & & & $0.5^{\mathrm{a}}$ & & & $20^{\mathrm{b}}$ & & & \\
\hline
\end{tabular}

${ }^{\mathrm{a}}(\mathrm{P} . \mathrm{L}$.$) permissible limits(ppm) for tissues FAO / WHO, (1992). (Pb, Cd)$

b(P.L.) permissible limits(ppm) for pearson, (1976) for $(\mathrm{Cu})$ 
Assiut Vet. Med. J. Vol. 57 No. 131 October 2011 